\title{
Adrian Pablé*
}

\section{Global Semiotics vs. Human Semiology}

\section{Understanding communication in the 21st century}

\begin{abstract}
This paper adopts as its point of reference an integrational semiology as developed by Oxford Professor of linguistics Roy Harris. It contrasts two contemporary approaches to communication as proposed by global semiotics and Saussurean semiology. Against the former, integrational linguists argue that there is no 'science' of communication (i.e., there is no way to isolate communication as a 'thing' and only then decide what is rightly called communication), and against the latter that there are no impersonal languages determining for its speakers what counts as communication and what does not. The paper introduces the Harrisian semiological notion of radical indeterminacy and suggests that a linguistics of the 21st century should be 'lay-oriented' and should recognize that individuals possess unique communicational histories.
\end{abstract}

Keywords: integrational semiology; global semiotics; radical indeterminacy; Saussurean semiology

*Corresponding author, Adrian Pablé: University of Hong Kong, E-mail: apable@hku.hk

\section{Introduction: The 'mystery' of communication}

In his contribution to the present issue, Noam Chomsky concedes that "the unbounded use of [the] finite means", i.e. "the actual production of speech in the free and creative ways that intrigued the great figures of the past" is still a mystery to this day and is likely to remain so permanently. In other words, for Chomsky human verbal communication might never be completely understood. There is no 'science of communication', while there is a 'science of language', i.e. "the study of the finite means" which, according to Chomsky, is best left to the "generative enterprise".

In my contribution I shall not pursue the question whether generative linguistics, and cognitive science more generally, have advanced our knowledge of what 'language' (and 'a language') is and whether its achievements might not rather be derived from a certain way of thinking about 
language (and languages) - a particular philosophy of language - than from any rigorous scientific inquiry. Oxford Professor of linguistics Roy Harris tackled these and other questions pertinent to generative linguistics in great detail (e.g. Harris, 1987; Harris, 1997) as part of his trenchant critique of what he had come to call the Language Myth (Harris, 1981), namely the theses that languages are fixed codes and that verbal communication is a form of 'telementation' (thought transference). To the best of my knowledge, Chomsky never responded to the Harrisian critique, though Borsely and Newmeyer (1997) did, remaining, however, the only ones in the generativist camp to have done so.

Roy Harris' linguistics, which he termed integrational linguistics (1998), is 'lay-oriented': for this reason he could not have agreed with Chomsky's view that the free and creative production of speech is 'mysterious'. It might be if one seeks a scientific, i.e. an impersonal, perspective. However, from my own point of view, i.e. based on my personal linguistic experience, human communication is not 'mysterious' at all. How, then, can I express myself freely and creatively? I do so because at any point in time of my life I have got a personal history - and having had experiences in the past I also have memories of them, making it possible for me to anticipate my immediate communicational future. I have got experience of 'interpersonal' communication, i.e. talking and listening to other people, writing to them and reading what they have written; I also have experience of communicating to myself, both in thoughts, speech, and writing. I have a mind and a body with which I experience communication, and I experience it as an open-ended process, i.e., I experience communication as an ongoing process and any delineation of when a communicational episode starts and ends as a matter of contextualized interpretation. I experience communication as occurring in the here-and-now and as making sense to me only because I have an immediate past and an immediate future that the hereand-now connects with. I experience communication as making all the difference depending on whether I know or don't know the person I'm communicating with. If I write a note to myself it has to be legible only to me; if I write a note meant to be read by someone else I will engage in very different 'integrational' tasks, both psychologically and biomechanically: I have to take into account who I am writing that note for (my wife, my children, the postman, an imaginary person, etc.). My experience also tells me that when I listen to conversations in languages unknown to me I do still make some sense of what is being said, i.e. I'm producing meaningful signs for myself. And I assume that my fellow-beings also experience communication fundamentally like that, though I cannot experience anybody else's experiences of communication. Human communication becomes 'mysterious' if we posit that there must be a shared language, i.e. a shared system of given signs (given words), underlying 
the communication that I personally experience as having and those episodes I remember having had. In other words, the 'mystery' arises as a consequence of treating human freedom and human creativity as requiring what Chomsky (1996: 100) calls "a system of constraints and governing principles" (see Pablé, 2012). The mystery is a consequence of distinguishing between finite means and their free and creative use: that is, it is a consequence of treating signs as determinate rather than indeterminate.

In this article I focus on the question of 'communication' as viewed within two schools of thought taking their inspiration from Peircean semiotics and Saussurean semiology, respectively. Neither school, however, argues that human (verbal) communication is a permanent mystery, while they both differ from Harris' account of what human communication is. The fundamental difference, in fact, lies in the question of (in) determinacy.

\section{Global semiotics vs. human semiology}

So what is communication? A thing? A word? An idea? If it is a 'thing', then the question resembles other ontological questions asked in science: there is something that communication 'is'. Semioticians of a Peircean tradition take a global view on communication - for them, the question 'what is communication?' is superordinate to questions like 'what is human communication?', 'what is animal communication?', 'what is cellular communication?', or questions like 'how does human communication differ from non-human communication?'. It is not that semioticians are not interested in the qualifications and comparisons just mentioned, but rather they believe that the thing 'communication' transcends species-specific considerations: it is obvious that, say, bacteria and humans communicate differently, and it is essential to find out how either kind of communication works. On the other hand, it is beyond doubt that both bacteria and humans do engage in 'communication'. Such a view distinguishes culture-specific questions around communication from scientific questions on communication. In a scientific paradigm it is not pertinent whether a certain people or a certain tribe believe, say, that stones communicate: either stones communicate or they don't. This approach is typical of the kind of semiotics that takes a global and totalizing view on communication, hence 'global semiotics'. Other scholars treat communication as the prerogative of human beings; they tend to give preference to verbal communication and tend to regard non-verbal communication as a somewhat inferior form of communication. This approach 
is typical of Saussurean semiology. Semiologists are interested in how human verbal communication works, and respectively how cultural and historical factors determine our view of communication. Saussure provided his students with a universal model of human verbal communication (known as the 'talking heads' model). At the same time, however, Saussure laid the theoretical foundations for treating human languages as semi-closed systems determining speakers' (biased) views of reality.

Despite their different outlooks, underlying both semiotics and semiology there is a certain conception of how human communication works, in particular how human verbal communication works. For instance, the semiotician Susan Petrilli assures her readers that when it comes to the term intercellular communication', which denotes communication between cells, "nobody would misunderstand that reference is to two people communicating with a mobile" (2015: 219). That nobody would interpret intercellular communication in this way presupposes a theory of the verbal sign that regards it as having a fixed meaning, sanctioned - not by the language-user - but by the language itself and the contexts of use. For the semiotician, communication is crucially about signs. Thomas A. Sebeok - like Peirce - believed that "the whole universe is perfused with signs" (in Petrilli, 2015: 173), and hence that the whole universe communicates. Semioticians take a very broad (i.e. global) approach to 'communication': nonhuman communication and human communication are treated as equally accessible to empirical research. The semiologist, in turn, holds that communication is a human and highly culture-specific concept, i.e., one cannot separate questions about the thing 'communication' from questions about the word communication: these questions are bound to the speech community that shares a certain language. The semiological school discussed here, Anna Wierzbicka's Natural Semantic Metalanguage (NSM), subscribes to a strong relativist position on language and communication. Both approaches, global semiotics and NSM theory, have been discussed in greater detail from an integrational linguistic perspective (however, not with special reference to communication) by Pablé and Hutton (2015) and Wawrzyniak (2010), respectively.

\section{The 'signs of life'}

In a recent article, Susan Petrilli (2015) tells her readers "global semiotics provides a meeting point and observation post for studies on the 'signs of life' and 'life of signs"' (p. 173). Petrilli quotes Sebeok as saying "semiosis, that is 
sign activity and life converge" (p. 173): they are co-extensive. For Sebeok it is axiomatic that "semiosis is the criterial attribute of life" (p. 173). To maintain and produce life necessarily involves signs. Echoing Sebeok, Petrilli warns against a shortsighted, i.e. an anthropocentric and glottocentric approach to signs, such as typical of semiologists, in particular the Saussureans. According to Petrilli, the Saussurean program of studying signs "as part of social life" has led to the so-called 'pars pro toto' fallacy (p. 175). The fallacy consists in the tendency to exchange verbal semiosis for semiosis in its totality, and to treat the verbal sign model as a general model of the sign (p. 191). Petrilli argues that for the semiotician there exists a biosphere in which messages / emitters / generators / sources / interpreteds, on one hand, and addressees / receivers / interpretants, on the other, all belong to one and the same gigantic semiosic network. (p. 199)

Sebeok called this network, or web, the 'semiosphere'. It is interesting to notice that the kinds of communication supposedly taking place in this semiosphere are highly reminiscent of human verbal communication, as usually envisaged within mainstream linguistics: there is a 'message' communicated by an 'emitter' (or 'sender') on one end that is to reach an 'addressee' (or 'receiver') at the other end. At the same time, however, Petrilli emphasizes that the 'signs of life' are for the most part nonverbal ones:

[...] it is the nonverbal sign that invests terrestrial semiosis overall and constitutes the distinctive characteristic of life itself. In four of the five superkingdoms [...], semiosis is uniquely nonverbal; only in the fifth, that which is inhabited by the animal called Homo sapiens sapiens, do verbal signs come on to the scene to join nonverbal signs. (p. 204)

As Petrilli sees it, biologists have provided the necessary proofs that communication is not bound by what ordinary language allows the word communication to mean. For the semiotician, therefore, it is not relevant that it sounds right (for English speakers) to say that animals communicate, and perhaps that it equally sounds right in contemporary English to say that bacteria communicate. That alone does not warrant the conclusion that animals or bacteria 'really' do communicate. Since communication is a 'thing', it is a question for biologists, among other scientists, to determine the correct definition of communication for purposes of science communication - which also means that it certainly isn't the lexicographer's job nor, ultimately, the lay speaker's. In Petrilli's (2015) own words:

Studies in the sphere of biology now reveal that members forming the other two super kingdoms, plants and fungi, also qualify as communicating. Not only: communication is also present in microorganisms. Communication involves cells endowed with an 
unencapsulated nucleus, that is, prokaryotes and bacteria. And it also involves the more developed cells endowed with an encapsulated nucleus, that is, eukaryotes. (p. 218)

Following Sebeok, Petrilli proposes a view of communication that is coextensive with life itself, although this, as she admits, may not be the entire story: "In fact, whilst it is not certain that where there is no life, there is no communication, there is no doubt that where there is life there is communication" (p. 219).

\section{Understanding communication through modern science}

Global semiotics, therefore, is the attempt of placing homo sapiens in its proper place: signs (and thus communication) existed long before the advent of mankind and long before the introduction of the metasign, of which only human beings are capable. This recognition would seem to open up completely new ways of understanding communication. However, as I am going to argue, we also seem to be unable to conceive of nonhuman communication other than in terms of human communication - a thesis that the semiotician would clearly reject. In order to make my point, I am going to discuss communication in relation to contemporary research on microorganisms. In 2009, Princeton molecular biologist Bonnie Bassler delivered a TED talk, in which she described bacterial communication, which occurs at a level that Roy Harris (2005: 178) has termed 'subanthropic' (i.e. at a level beyond the reach of the unaided human senses), by resorting to vocabulary belonging to the 'anthropic' experience of communication. ${ }^{1}$

At the beginning of her talk, Dr. Bassler said, half-humorously, that she prefers to think of humans as 1-10\% 'human' and $99-90 \%$ 'bacterial'. So it would seem that for Bassler to understand human beings you need first of all to understand bacteria. What Bassler does in her explanations, however, is precisely the opposite: she anthropomorphizes bacteria. Keeping in mind that we may only be $1 \%$ 'human', what Bassler may be implying here is that the terminology typically used for human communication ('communication', 'language', 'words') is actually, from an evolutionary perspective, the terminology pertinent to bacteria. Bacteria had a 'language' - and 'words'

$1 T E D$ - an acronym for Technology, Entertainment, Design - denotes an Internet lecture series. 
making up that language - way before human beings developed human languages and human words. So the question is: does Bassler regard the terms used to discuss bacterial communication as metaphorical at all?

Bassler's triggering experiment involved an oceanic bacterium that, when in a community of fellow-bacteria, makes light (together with all the other bacteria of its kind), whereas when it is alone it does not. As Bassler (2009) states:

The question that we had is how can bacteria, these primitive organisms, tell the difference from times when they're alone, and times when they're in a community, and then all do something together. What we've figured out is that the way that they do that is that they talk to each other, and they talk with a chemical language.

\section{This 'chemical language', Bassler tells us, consists of 'chemical words':}

This is now supposed to be my bacterial cell. When it's alone it doesn't make any light. But what it does do is to make and secrete small molecules that you can think of like hormones, and these are the red triangles, and when the bacteria is alone the molecules just float away and so no light. But when the bacteria grow and double and they're all participating in making these molecules, the molecule - the extracellular amount of that molecule increases in proportion to cell number. And when the molecule hits a certain amount that tells the bacteria how many neighbors there are, they recognize that molecule and all of the bacteria turn on light in synchrony. That's how bioluminescence works - they're talking with these chemical words.

\section{About the molecules found in the bacteria, Bassler goes on to say:}

The left-hand part of the molecule is identical in every single species of bacteria. But the right-hand part of the molecule is a little bit different in every single species. What that does is to confer exquisite species specificities to these languages. Each molecule fits into its partner receptor and no other. So these are private, secret conversations. These conversations are for intraspecies communication. Each bacterium uses a particular molecule, that's its language that allows it to count its own siblings.

Bassler tells us that bacteria are 'multilingual': they have their own 'native language', but are also fluent speakers of a 'lingua franca', shared by all different kinds of bacteria:

So we went back to molecular biology and started studying different bacteria, and what we've found now is that in fact, bacteria are multilingual. They all have a species-specific system -they have a molecule that says "me." But then, running in parallel to that is a second system that we've discovered, that's generic. So, they have a second enzyme that makes a second signal and it has its own receptor, and this molecule is the trade language of bacteria. It's used by all different bacteria and it's the language of interspecies communication. What happens is that bacteria are able to count how many of me and how 
many of you. They take that information inside, and they decide what tasks to carry out depending on who's in the minority and who's in the majority of any given population. [...] What the important thing is that we learned is that every bacterium has exactly the same enzyme and makes exactly the same molecule. So they're all using this molecule for interspecies communication. This is the bacterial 'Esperanto'. [...] Once we got that far, we started to learn that bacteria can talk to each other with this chemical language. But what we started to think is that maybe there is something practical that we can do here as well. I've told you that bacteria do have all these social behaviors; they communicate with these molecules.

So bacteria do 'in-group' talking, but they also engage in 'interspecies communication': in either case the communication works because they 'speak' the same 'language'. Human beings did not invent the codes that we think human languages are. Bassler grants bacteria with being inventors of 'simple systems'.

This is exactly what happens in your body. It's not like your heart cells and your kidney cells get all mixed up every day, and that's because there's all of this chemistry going on, these molecules that say who each of these groups of cells is, and what their tasks should be. Again, we think that bacteria invented that, and you've just evolved a few more bells and whistles, but all of the ideas are in these simple systems that we can study.

Bassler's research aims at overcoming the drug-resistance of bacteria to antibiotics by disturbing both the bacteria's intraspecies and interspecies communication, i.e. to prevent them from talking to each other, which means to prevent them from counting the number of bacteria and hence launching their attacks on the human organism. Bassler concludes her TED talk as follows:

We think that this is the next generation of antibiotics and it's going to get us around, at least initially, this big problem of resistance. What I hope you think, is that bacteria can talk to each other, they use chemicals as their words, they have an incredibly complicated chemical lexicon that we're just now starting to learn about.

Bassler believes that bacteria have a personal identity and know that other bacteria have one too. They are 'human-like' - or rather we are 'bacteria-like':

I hope that what you've learned is that bacteria can distinguish self from other. By using these two molecules they can say "me" and they can say "you".

So Bassler seems to think that there is a lot for us to learn about ourselves from bacteria. This hardly passes muster as a 'humanist' discourse in the traditional sense. As Bassler herself says, humans have "just evolved a few more bells and whistles" - we are not as special as we thought we were. 
It could be argued that the terminology used by Bassler in her TED talk, familiar from human linguistic affairs (e.g.'communication', 'language', 'words', 'lexicon', 'conversation', 'talking to each other', 'saying') serves to make her research understandable to an educated lay audience. It could therefore be argued further that Bassler never intended us to really believe that bacteria 'talk to each other'. And yet, there is the feeling that Bassler is talking about 'things': if Bassler uses the terms chemical language and chemical words, this 'language' and these 'words' are not supposed to reveal themselves, in a later phase of research, as something totally different. It is unlikely that Bassler will step forward in the future and declare: 'we first thought that bacteria were communicating via a chemical language consisting of chemical words, but it turns out that it is not at all like a language and these are certainly not words they are using. Actually bacteria aren't really communicating after all'. Bassler, it seems to me, expects words (in their function as names) to be mirror images of reality when part of scientific discourse. She would not want her audience to think that she is merely attaching her own private ideas to words such as 'language' and 'communication'. To use the word communication correctly in science talk is to use it in connection with the right referent: thus, bacteria 'communicate' if they really communicate. That communication is an English word doesn't seem to worry Bassler in the least. Bassler, as I see it, isn't speaking metaphorically after all.

Semioticians would certainly not approve of Bassler's anthropomorphizing discourse: bacteria don't really 'talk to each other', the semiotician would likely protest, adding that Bassler is guilty of committing the 'pars pro toto' fallacy. At the same time, they would fully agree with Bassler that bacteria do communicate, and they would add that they do so by means of signs. Doesn't Bassler's research demonstrate precisely this? But Bassler never cares to define what a sign is - in fact, she is talking about bacteria as if they were capable of signs that are like verbal signs - nor does she think it necessary to provide her audience with a definition of communication. Presumably, for her, a sign is anything that someone/something interprets as standing for something particular. Susan Petrilli (2015: 226) herself doesn't find it strange to use the verb interpret in conjunction with microorganisms and the immune system. Hence: bacteria interpret this or that as 'standing for' this or that. The semiotician argues that every creature has its own species-specific Umwelt in which it generates signs - an insight developed by the 'cryptosemiotician' Jakob von Uexküll. We - human beings - assign meanings to signs according to the human Umwelt, but at the same time we can develop an understanding of what the signs 'mean' for animals, bacteria, fungi, cells, etc. Following Thomas A. Sebeok, the pure fact of living is already to display 'signs of life' and to enable 
us to study the 'life of signs'. Therefore: life presupposes signs, and where there are signs there is communication.

\section{The cultural relativity of communication}

Semiologists of a Saussurean creed, in turn, approach the issue of 'communication' in an altogether different manner. Here communication is not a culture-neutral 'thing', a phenomenon of objective reality, but instead a culture-laden word that has its own language-specific semantic history, as recorded by dictionaries based on historical principles (such as the OED). Whether bacteria 'really' have a language or whether they 'really' do communicate is a superfluous question within semiology, not because the semiologist denies that there is an objective reality, but because for Homo sapiens knowledge of this objective kind is an illusion created by science. Reality, for the semiologist, is a social construct made possible by the abstract linguistic system shared by a community of people. If in contemporary English the verb to communicate can be used in connection with bacteria, then this is what is 'real' for contemporary speakers of English: bacteria communicate. The community of scientists using scientific English are subject to the very same discursive constraints imposed on them by the system of that particular vehicle language. This, however, does not imply that members of other speech communities would say of bacteria that they 'communicate' in their respective languages. For the semiologist the English word communication, when used in academic discourse, is not simply an international, and thus mutually understandable, term. For example, the linguist Anna Wierzbicka (2006) recalls the awkwardness of having to teach a course in intercultural communication at a Polish university:

The current international career of the concept 'communication' is a good case in point. It is a concept well entrenched in the English language [...] and quickly spreading into other languages, including, for example, my native Polish. During my student days, in colloquial Polish the word komunikacja referred to transport and traffic, not to speech, and when I started to teach a course on cross-cultural communication I couldn't translate this readily into Polish, because there was no (non-technical) word in Polish for 'communication' in that sense. Today, speakers of Polish would readily use for this purpose the old Polish word komunikacja, with a new meaning, which appears to have come into the Polish conceptual world through English. (p. 682)

Thus academic discourse becomes streamlined via semantic loans, but this does not happen in all languages and across all domains. Anna Wierzbicka and 
her colleague Cliff Goddard developed a linguistic theory known as Natural Semantic Metalanguage (NSM) that is meant to bring about conceptual clarity when it comes to conceptually complex, language-specific words. The meaning of the English word communication, for example, is inextricably bound to an 'Anglo' way of thinking, itself historically related to John Locke. As Goddard (2009) assures us:

[...] the word communication (not to mention system) is both semantically complex and highly language-specific. Even many languages of Europe do not have a word exactly matching the particular semantic configuration we find in the modern English word communication. (p. 12)

In connection with the word communication, Goddard identifies two other words, namely message and information, which are said to constitute "a key cultural model of modern Anglo culture". According to Goddard (2009: 15), when we say that the addressee 'understands' what the speaker 'means' we are also putting things in very 'English-specific terms'. The English verb to mean establishes a connection between the 'meaning' of words and the 'intention' with which these words are used ('I didn't mean it in this sense'). A leading model of communication in pragmatics, in fact, conceives of successful communication in terms of the hearer getting the 'intentions' behind the speaker's words. The intentionalist model of communication, it could be argued, also corresponds to an 'Anglo' way of thinking, going back to philosophers of language Grice and Searle. In his article on how the 'communication' concept has been approached in pragmatics, Michael Haugh (2009: 91) identifies two strands, namely an 'Anglo-American' pragmatic school and a 'EuropeanContinental' pragmatic school, the latter in fact paying more heed to the social and cultural constraints on language use.

At the same time, Goddard fails to tell his readers what philosophy of communication he himself subscribes to. For talking about communication (as Goddard does) presupposes a model of communication. There is little doubt that, as a Saussurean and linguistic relativist, Goddard assumes that human verbal communication is 'telementational', that is, in order to be communicated, words have to trigger the same concepts in the speaker and listener's minds (or respectively the writer and reader's minds), and that 'telementation' works because languages (as well as dialects and linguistic varieties) are 'codes'. Goddard hardly wishes to argue that because the word communication and its 'equivalent' cognate words in other languages mean different things to speakers of different languages, the way human verbal communication 'is' also differs. The lay speakers don't see the 'reality' of communication because their vision is 
obfuscated by the abstract mental linguistic system they possess as a result of having been born into a particular speech community. The linguistic theorists, on the other hand, when speaking qua theorists, are exempted from the constraints on cultural relativity: what they proclaim ex cathedra is not relative to the language they communicate in and communicate with, nor to the belief system they inherited as members of a specific culture.

Goddard (2009: 17) argues that according to the Anglo way of thinking the verb to communicate, referring to one person saying things to another person, always implies that this communication be 'efficient' or 'successful', and thus that "the speaker wants the addressee to understand well what he/she has to say". This is what Goddard sees as a "culture-specific attitude towards verbal interaction” typical of the Anglophone. He (2009: 17) goes on to say:

[...] from a position within Anglo culture (and within the English language), this attitude can seem so natural as to go unnoticed, but the fact is that people can say things to other people for a great variety of reasons.

He adds that when people say things to other people, in many situations "it may not be particularly important whether the other person knows exactly what one wants to say to them" (2009: 17). That the English verb to communicate implies full understanding (of meaning, intentions, etc.) between the speaker and the hearer is something that Goddard knows as a native speaker of contemporary English. It is one of the meanings that English dictionaries will attribute to the verb to communicate and the noun communication: it is a historically grown lexical meaning (Saussure's diachronic change), which is shared by a community of speakers at a certain point in time (Saussure's synchronic state). Saussure's position implies a highly deterministic view on 'reality' as linguistically and discursively mediated. Wierzbicka and Goddard have taken the logical step following from Saussure's theoretical point, which is to deny the possibility of using, say, English as a neutral language in which to discuss communication theory. To talk about 'communication' in English, as a native speaker of English, is to discuss it the Anglo way: the cultural bias cannot be overcome in any conventional human language - not even in scientific English. However, even if John Locke was the first one to use the English noun communication in a modern sense, thus focusing on the message content, which requires the matching of ideas in individuals' minds, he still did not pull his model out of a clear blue theoretical sky. Locke's model of communication owes much to Aristotelian semiotics: for Aristotle, words do not stand for the things they designate directly but via an identical mental impression each individual stores of the things in reality. As Roy Harris has argued throughout his career, a 
certain way of thinking about language and communication is endemic to Western intellectual thought (e.g. Harris, 1980). It is likely that Wierzbicka would not accept this thesis, saying that Harris cannot grasp the thought-worlds associated with Old Greek, Latin, and German (among others), and thus is in no position, as a twentieth-century Anglo writer, to identify this presumed common, millennium-old thread of thinking in a determinate way about signs, language, and communication. Ideas, for the linguistic relativist, cannot exist but as part of the abstract linguistic community code, the langue. If an idea spreads, then it needs a word to attach itself to, either a neologism or an already-existing word to which a new meaning is added. But could the Greeks or Romans have subscribed to a 'telementational' model of communication, as Harris has claimed, if they didn't have that word, or a different word with the equivalent meaning?

Goddard and Wierzbicka's point is that one mustn't be deceived into believing that cognate words, like English communication and Spanish comunicación, are semantically equivalent: as they would point out, the differences concern both the diachronic and synchronic levels in crucial respects. This only makes sense because Goddard and Wierzbicka adopt a Saussurean view of the sign, the sign consisting of an indivisible unity between signifier and signified. What a word means is what the abstract synchronic system allows it (or did allow it) to mean. Words themselves are polysemous, i.e. every word can have different (often related) meanings. As Wierzbicka (2006: 692) makes clear, word meanings are social facts: they cannot be changed at will and are not a matter of opinion.

Is crosslinguistic communication a cause perdue, then? Adherents to the Natural Semantic Metalanguage approach don't think so. What needs to be done when it comes to highly complex semantic configurations behind superficially familiar (and crosslinguistically accessible) words (like communication, language, dialogue, etc.) is to resort to a metalanguage for semantic/conceptual explication that consists of so-called 'semantic primes'; As Goddard (2009: 12) explains, these primes are "simple, indefinable meanings", which "appear as the meanings of words or word-like expressions in all languages". Examples of such semantic primes are people, someone, something, somewhere, words, want, do, say, know, good, bad, because (among others).

Thus Goddard (2009: 18) offers the following semantic description of the English noun communication (in the sense of the hearer reaching, ideally, full understanding of what the speaker intended the addressee to understand):

communication

a) something

b) people can say what with the word communication 
c) people can want to say something about something with this word when they think like this:

d) 'It can be like this:

e) at some times someone wants to say some things to someone else

f) at these times this someone wants this other someone to know well what he/she wants to say

g) because of this, this someone says some things to this other someone

h) when he/she says it, this other someone can know well what this someone wants to say

i) it is good if it can be like this

j) it can be not like this if this someone says these things in another way'

Interestingly enough, the semantic explication of the noun communication presented here only makes sense because words are treated as having meaning independently of communication; the word communication itself is no exception. For example, what counts as 'saying things' or 'saying something' is highly context-sensitive, not only because it is culture-specific but also because individuals contextualize linguistic items constrained by factors of a biomechanical and circumstantial nature (Harris, 1998). There is no objective court of appeal passing judgment about whether someone really 'said something' to someone else. Speakers of English don't automatically agree on whether a particular instance of interaction would count as 'communication'. Are there objective standards for assessing whether someone 'said something' to somebody else? Pace Goddard and Wierzbicka, presumed 'universal' (and hence language-neutral) concepts expressed in English as say and something are treated like any other language-specific words: thus, the word say needs to be interpreted by someone as that particular word in the first place. Semantic primes have to be formulated as words of some natural language. Simply claiming that the semantic primes are abstract concepts (they are language-less) in spite of their 'outer appearance', which is language-specific, puts the cart before the horse. It doesn't constitute evidence that universal semantic primes exist.

The conceptual explication proposed by the natural semanticists is meant to remedy the fact that language-specific words are not translatable crossculturally, at least not in the sense that there is an exact equivalent in language $B$ of a word belonging to language A. The semantic primes thus enable speakers of different languages to talk about 'things' as perceived from the 
point of view of one particular language. Through the componential semantic analysis proposed in NSM, anyone can learn what meanings are ascribed to the English word communication, i.e. the word is made completely transparent.

\section{Semiotics, semiology, and philosophy of language}

The two approaches to communication discussed here both assume that words, in their function as names, 'stand for' something. In the global semiotic framework communication is a 'thing' that the word communication (and its equivalent terms in other languages) identifies. The semiotician has decided that any life form is engaged in semiosis, thus in sign-making. Where there are signs, moreover, there is communication. Thus: to say that bacteria, the immune system, plants, and insects communicate - and not only human beings - is merely to state what scientific research has shown to be true. Culturespecific reservations are not the semiotician's concern, as scientific English is not primarily interested in any cultural and historical connotations of the English word communication. Names in scientific English are substitutes for the things themselves: they are, in some sense, 'culture-less'. The semiologist, in turn, regards phrases like animal communication or sentences like cells communicate with each other or two computers that communicate as "extended uses of the core meaning of communicate" (Goddard, 2009: 16), that is they are social facts of the language: these uses are perfectly fine as long as we keep in mind that it is the English language that allows us to postulate that cells 'communicate'. At the same time, it seems that these 'extended uses of the core meaning of communicate' have become the core meaning of the word within academic linguistic circles. As Timothy Curnow (2009: 30) tells us, certain introductory textbooks to linguistics (e.g. Fromkin \& Rodman, 1978; Fromkin, Rodman et al., 2005; O'Grady et al., 1997) use the word communication very sparingly, in fact hardly ever in connection with human communication, but rather in connection with animal communication or computer communication. According to Curnow, for many academic linguists nonhuman communication contrasts with human language/languages.

Thus, from the point of view of human semiology, American molecular biologist Bonnie Bassler found that bacteria communicate because she is a speaker of English. Perhaps if she had been a speaker of Armenian or Urdu she wouldn't have used a term in her language comparable to the English noun communication, and hence she would have understood and explained her 
research and her findings in a very different manner. Goddard argues that scientific terminology should be "detached from the grip of any single language" (2009: 24) in order to enable a kind of scientific communication that does not suppress the unavoidable culture-specificity of any language or any register. He adds, "the more promising approach would be to decompose these and other useful, but language-specific terms, into configurations of semantic primes" (2009: 24). Needless to say that natural scientists will hardly be interested in decomposing each and every conceptually complex word that plays a role in their research into configurations of semantic primes. It is not clear whether the NSM people would expect that from natural scientists. However, the humanities are advised to follow this procedure. As Goddard states,

[N]either communication nor language (nor competing terms such as discourse, interaction, semiotics, 'languaging', etc.) are suitable conceptual tools for the human sciences [...]. (2009: 24)

So on the one hand we find the position that communication is useless as a metalinguistic term in the humanities; on the other hand we encounter the position that the word communication can be applied to any referent unhesitatingly. In spite of two philosophies of language that seem to be diametrically opposed, both the semiologist and the semiotician regard verbal signs as determinate. For both there is a link between the name and what it stands for: in one case the link is determined by mind-independent reality; in the other case the link is established in the act of speech as determined by the value assigned to that word in the overall structure of the language, i.e. how reality has been divided up by a speech community.

\section{Conclusion: An alternative semiology}

But what if signs were indeterminate? What if the word communication cannot fulfill the respective expectation of designating a thing of objective reality (independently of context), and being a word whose meaning is shared by millions of speakers who all participate in the same social contract that is 'language'? Let's adopt the alternative sign theory, i.e. one based on indeterminacy (as postulated by Roy Harris). According to this theory, it is wrong to justify the word communication based on the claim that there is a 'thing' that the word faithfully depicts. According to this theory, it is also wrong to argue in favor of the existence of an abstract word communication, which is 
supposed to (miraculously) mean 'the same' to each and every native speaker of English because it is embedded in a historically grown collective mental structure. Rather, the sign communication is not 'given' (either in concordance with mind-independent Nature or as established by human collectivities): as the integrational linguist argues, in order to count as a sign someone has to make it a sign of something. This recognizes that for human beings there cannot be a final answer to the question "What is communication?", but it also rescues us from having to resign to the fact that communication is 'merely' a word - an English word to boot - and that therefore we cannot talk meaningfully about 'communication' in English (or in any other language). To assume otherwise is to surrender to language itself - one way or the other - and by doing so to give up our very 'humanity'. The alternative theory that Harris envisaged admits that signs are personal (they are part of my personal communicational experience), which is not to be understood as a denial of the social constraints on communication. My personal experience of the word communication also includes my experience of other people in relation to this presumably 'identical' word. However, what 'communication' is and what the word communication means for other people, one cannot tell from any other perspective than that of one's personal communicational experience.

Perhaps until today you didn't know that bacteria communicate, or if you did you may not have known that they do so by 'talking to each other' or by 'conversing with each other', using two different 'languages' consisting each of a 'lexicon'. Perhaps you can say that the word communication has acquired a new meaning for you as a result of this personal communicational encounter. It doesn't follow from this, however, that you are forced to admit having advanced your knowledge of what communication 'is'.

How, then, can we advance our knowledge of communication in a way commensurate with twenty-first century scientific progress? I don't think the Harrisian linguist can give a satisfactory answer to this question, his domain being that of philosophy of language. What is clear to the Harrisian linguist, however, is that even the very best science is founded on certain semiological assumptions: it could be argued against integrational linguists that these assumptions have stood the test of time, but this is so only because they were never seriously questioned - until Roy Harris introduced his tenet of the radical indeterminacy of the sign (e.g. Harris \& Hutton, 2007: 201). The time has come for demythologizing twenty-first century linguistics (and the semiological theories it sponsors); no profit can be gained from waiting for another hundred years. 


\section{References}

Bassler, B. (2009). How bacteria 'talk'. TED conference talk.

https://www.ted.com/talks/bonnie_bassler_on_how_bacteria_communicate/transcript?langu age $=$ en. (Accessed 9 December 2015).

Borsley, R., \& Newmeyer, F. (1997). The language muddle: Roy Harris and generative grammar. In G. Wolf \& N. Love (Eds.), Linguistics inside out: Roy Harris and his critics (pp. 42-64). Amsterdam: John Benjamins.

Chomsky, N. (1996 [1970]). Language and freedom. Reprinted in Resonance, 4(3), 86-104.

Curnow, T. (2009). Communication in introductory linguistics. Australian Journal of Linguistics, 29(1), 27-43.

Fromkin, V., \& Rodman, R. (1978). An introduction to language. (2nd edition). New York: Holt, Rinehart and Winston.

Fromkin, V., Rodman, R., Hyams, N., Collins, P., \& Amberber,M. (2005). An introduction to language. (5th Australian edition). South Melbourne: Nelson Thomson.

Goddard, C. (2009). The 'communication' concept and the 'language' concept in everyday English. Australian Journal of Linguistics, 29(1), 11-25.

Harris, R. (1980). The language-makers. London: Duckworth.

Harris, R. (1981). The language myth. London: Duckworth.

Harris, R. (1987). The language machine. London: Duckworth.

Harris, R. (1997). From an integrational point of view. In G. Wolf \& N. Love (Eds.), Linguistics inside out: Roy Harris and his critics(pp. 229-310). Amsterdam: John Benjamins.

Harris, R. (1998). Introduction to integrational linguistics. Oxford: Pergamon Press.

Harris, R. (2005). The semantics of science. London: Continuum Press.

Harris, R., \& Hutton, C. (2007). Definition in theory and practice: Language, lexicography and the law. London: Continuum Press.

Haugh, M. (2009). Intention(ality) and the conceptualization of communication in pragmatics. Australian Journal of Linguistics, 29(1), 91-113.

O’Grady, W., Dobrovolsky, M., \& Katamba, F. (Eds.). (1997). Contemporary linguistics: An introduction. (UK edition). London: Longman.

Pablé, A. (2012). Excommunicated on the grounds of Harrisy: Roy Harris, linguistics and freedom of speech. In W. Finke \& L. Ashley (Eds.), Language under controls: Policies and practices affecting freedom of speech (pp. 1-12). New York: Cummings \& Hathaway.

Pablé, A., \& Hutton, C. (2015). Signs, meaning and experience: Integrational approaches to linguistics and semiotics [Semiotics, Communication and Cognition 15]. Berlin: Mouton de Gruyter.

Petrilli, S. (2015). Language, communication, and speech: Human signs in global semiosis. Semiotica, 204, 173-237.

Wawrzyniak, J. (2010). Native speakers, mother tongues and natural semantic metalanguages. Language Sciences, 32(6), 648-670.

Wierzbicka, A. (2006). The concept of 'dialogue' in cross-linguistic and cross-cultural perspective. Discourse Studies, 8(5), 675-703. 


\section{Bionote}

\section{Adrian Pablé}

Adrian Pablé (b. 1971) is Associate Professor of linguistics in the School of English at the University of Hong Kong. He is the Secretary of the International Association for the Integrational Study of Language and Communication (IAISLC) and series editor of the Routledge Advances in Communication and Linguistic Theory. His latest book Signs, meaning and experience: Integrational approaches to linguistics and semiotics (co-authored with C. Hutton) was published by Mouton de Gruyter in 2015. 